\title{
Update DLT Linz 2017
}

Ultraschall 2017 - News:

- Abstracteinreichung offen, Deadline 02. Juni 2017

- Programm auf der Website bereits einsehbar

- Anmeldung zum Dreiländertreffen möglich - bis 06. September zu reduzierten Teilnahmegebühren!

- Anmeldung zum Studentenprogramm möglich

- Dussik-Lecture unseres neuen Ehrenmitglieds Prof.Dr. Reinhard Graf (11.10.2017 | 17:45): „30.000 Jahre Hüftgelenk, 30 Jahre Hüftultraschall“ 